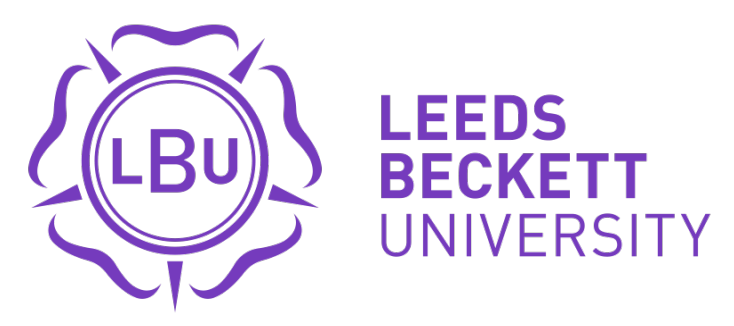

Citation:

Mitchell, L (2013) Monsters, Martyrs, Heroes, and their Storytellers: The Enduring Attraction of Culturally Embedded Narratives in the ;War on Terror'. Liverpool Law Review. ISSN 0144-932X DOI: https://doi.org/10.1007/s10991-013-9146-8

Link to Leeds Beckett Repository record:

https://eprints.leedsbeckett.ac.uk/id/eprint/4453/

Document Version:

Article (Accepted Version)

The aim of the Leeds Beckett Repository is to provide open access to our research, as required by funder policies and permitted by publishers and copyright law.

The Leeds Beckett repository holds a wide range of publications, each of which has been checked for copyright and the relevant embargo period has been applied by the Research Services team.

We operate on a standard take-down policy. If you are the author or publisher of an output and you would like it removed from the repository, please contact us and we will investigate on a case-by-case basis.

Each thesis in the repository has been cleared where necessary by the author for third party copyright. If you would like a thesis to be removed from the repository or believe there is an issue with copyright, please contact us on openaccess@leedsbeckett.ac.uk and we will investigate on a case-by-case basis. 


\title{
Monsters, Heroes, Martyrs and their Storytellers: The Enduring Attraction of Culturally Embedded Narratives in the 'War on Terror'
}

\author{
Lynsey Mitchell \\ University of Strathclyde \\ 01414448455
}

Lynsey.mitchell100@strath.ac.uk

\begin{abstract}
This paper begins by exploring how traditional Manichean and binary narratives, which are familiar to us from fairy-tales, were used to justify the 'War on Terror' and then engages critically with the feminist and critical scholarship which argues that such narratives helped silence the wider geopolitical and legal discussions. Whilst this paper concurs with the large volume of literature that concludes that the heroic narrative obscures the political reality and marginalises the subjects of this narrative, it takes issue with some of the assumptions underlying this literature. This paper argues that many feminist scholars who critique the heroic narrative of the 'War on Terror' have fallen victim to the same oversimplification that the narrative itself deploys. While those scholars are correct to identify the operation of the heroic narrative within the rhetoric on the 'War on Terror', their continued focus solely on this narrative masks the more complex racialised, Marxist and identity narratives that also operate within this rhetoric.
\end{abstract}

Key Words

Afghanistan, feminism, narratives, terrorism, 'War on Terror'.

\section{Introduction}

According to Shelley Wright international law would be meaningless without narrative. ${ }^{1}$ She writes that "we cannot imagine what we cannot tell as a story". ${ }^{2}$ This builds on the work of Robert Cover, which argued that all legal tradition is part of a complex 'nomos'- a normative arena that can only be understood through familiar narratives- and that one cannot operate in this nomos without an objective

\footnotetext{
${ }^{1}$ Wright (2002) p.233

${ }^{2}$ Ibid.
} 
understanding of these narratives. ${ }^{3}$ As such, the focus of this paper is on the legal and non-legal literature written in the wake of the 9/11 attacks, which argued that the dominant discourse focussed on the human rights abuses of Afghan women in order to frame the 'War on Terror' as a rescue mission, casting the west as the hero and the Islamic terrorists and fundamental Taliban as the villain. ${ }^{4}$ Such scholarship utilises Cover's theories to argue that the military intervention in Afghanistan, known as Operation Enduring Freedom, (OEF) was located firmly within a heroic narrative that ultimately situates the 'War on Terror' as a Manichean clash of civilisations.

In order to critique this literature, this paper will firstly outline the construction of the heroic narrative in the 'War on Terror' and its documented ill effects. However, while this paper agrees that a hegemonic discourse representing the 'War on Terror' as a Manichean clash of civilisations does indeed seek to saturate and over-determine the debate, it does not support the assertion in much of the literature that this was the only narrative interpretation possible. Instead this paper argues that the heroic narrative critique reaches this conclusion by ignoring the wider fragmented narratives and focussing too heavily on the co-option of human rights rhetoric to justify the intervention. In doing so, the heroic narrative critique fails to truly deconstruct the discourse because although it criticises the binary depiction of villains and heroes, it does not adequately question the implicit casting of the West as the heroes and the East as the villains in this narrative.

As such, this paper criticises this scholarship for being overly attracted to the heroic narrative and subscribing to the same binary distinctions it criticises. It therefore concludes that those scholars who highlight the existence of the heroic narrative as a rejoinder to hawkish imperialism fail to escape the prism of their own experience and engage in reductivist assertions in order to make their claims.

\footnotetext{
${ }^{3}$ Cover (1983).

${ }^{4}$ Hunt and Rygiel (2006); Kolhatkar and Ingalls (2010); Fluri (2008); Ayotte and Husain (2005); Charlesworth and Chinkin (2002); Cooke (2002); Heathcote (2005); Hunt (2002); Jiwani (2009); Stabile and Kumar (2005); Tickner (2002); Lorber (2002); Cloud (2004).
} 


\section{The Heroic Narrative}

The idea that human rights and humanitarianism is grounded in familiar stereotypical narratives of victims, villains and heroes is not new. Indeed, Mutua argues that such a narrative lies at the heart of the human rights project. ${ }^{5} \mathrm{He}$ writes that it is a damning metaphor that "depicts an epochal contest pitting savages, on the one hand, against victims and saviours on the other." Indeed post-colonial scholarship has established that the arguments espoused by the colonial powers to defend their subjugation of third world countries was often grounded in this narrative. ${ }^{7}$ In international law this narrative operates as what Anghie and Chimni refer to as the 'civilising mission', ${ }^{8}$ or the idea of "white men saving brown women from brown men." 9 That is to say, Western states saving Third World women.

Anne Orford and others describe how this narrative underpins international intervention by presenting rogue states, 'despotic dictators' and 'fanatical terrorists' as threats to the existing world order. ${ }^{10}$ Therefore military intervention by the West is then considered necessary to remove this threat, restore the existing order and save the people who are victims of this disorder. There are three key elements necessary to establish this narrative; the first is a disruption of the established symbolic order; the second is that there must be a hero, or "white knight' with whom the spectator is invited to identify and finally, the radicalised or feminised characters that serve as a background and foil to the actions of the hero.

The attraction of this narrative is that it reimagines childhood fairy-tales in which the (masculine) hero saves the (feminine) victim from a metaphorical evil. It is important to note that there is no succinct definition as to what is meant by the term fairy-tale. Indeed Smith notes that one of the main problems with the term is that many stories considered emblematic do not contain a single fairy. As such, according to Tolkien:

\footnotetext{
${ }^{5}$ Mutua (2001) p.201.

${ }^{6}$ Ibid p.201.

${ }^{7}$ Zine (2006); Anghie and Chimni (2003).

${ }^{8}$ Anghie and Chimni (2003) p.85.

${ }^{9}$ Spivak (1988).

${ }^{10}$ See Orford (2003); Orford (1999); Chandler (2006); Mutua (2001).
} 
The definition of a fairy-story - what it is, or what it should be - does not, then, depend on any definition or historical account of elf or fairy, but upon the nature of Faërie: the Perilous Realm itself, and the air that blows in that country. I will not attempt to define that, nor to describe it directly. It cannot be done. ${ }^{11}$

It is however true that the classical Western fairy-tale evolved centuries ago when storytellers began appropriating different kinds of magical folk tales, which they then edited and sanitized to reflect social and moral conventions of the day. These tales can be traced back to the oral storytelling traditions of European peasants and were appropriated from a particular genre; the magic tale that tended to focus on miraculous transformations that allowed the disadvantaged or dispossessed to succeed in life. Although the original tales were intended for adults, the continuing popularity of these tales in modern times is attributed to Walt Disney, whose films and books are aimed at children. Indeed it is thought that through these films, cartoons and books most children are familiarized with the tales. ${ }^{12}$ Therefore, when referring to fairy-tales, this paper restricts itself to this modern "conventionalized or Disneyfied notion" of what constitutes a fairy tale.

Jameson argues that this fairy-tale narrative (like many others) transcends fiction and permeates our culture. ${ }^{13}$ As such, in the human rights and humanitarian project it is often argued that this narrative exists to attract public support for military deployments by allowing ordinary people to buy into the myth that they are saving people, when in fact the evidence suggests the contrary. ${ }^{14}$ As such, the well-documented effects of this narrative are that it manages to oversimplify complicated geo-political issues; it reasserts a hawkish conservative masculine approach to international law and international relations, and it co-opts the language of human rights and women's rights while doing little to further these

\footnotetext{
11 Tolkien (1965: 16)

12 Zipes (2006) p.52.

${ }^{13}$ Jameson (1982).

${ }^{14}$ Orford (2003).
} 
causes and thereby damages the human rights movement by linking it to imperialist foreign policies. ${ }^{15}$

\section{The Operation of the Heroic (or Fairy tale) Narrative in the 'War on Terror'}

\section{The Hero}

All good tales require a hero. This character is obliged to be male and the story is invariably told from his perspective. In the Afghan narrative the heroes are the American and British people; variously represented by the soldiers fighting the 'War on Terror' or the ordinary people who continued their lives in the wake of terrorist atrocities. In this way everyone in the West is depicted as heroic and like the fairy-tale princes of old these heroes are stoic and determined. Their pure intentions, pursuance of justice and benevolent nature automatically render them and their quest magnanimous and altruistic.

While the depiction of militarism or power as chivalrous and just may at first appear an oxymoron, it is important to note that such a construction is not reserved to the 'War on Terror'. It is historically familiar in that support for war has often been achieved through such mythmaking. In ancient times epic literature, poetry and folktales such as the Iliad, the Aeneid, Beowulf or the legend of King Arthur glorified wars and those who fought in them. Warriors like Achilles were celebrated and their heroics were valorised and immortalised. As such, the depiction of the West and its soldiers as heroic can be seen as a readymade and attractive trope. However, while much of the literature that critiques the heroic narrative is correct to highlight the dangers of the hero characterisation, particularly for feminism, much of this literature fails to adequately challenge the assumptions under which this construction operates.

\section{i. The Hero as the Saviour}

It has been commented upon that in the days and weeks following 9/11 the White House invited Hollywood executives to a meeting where the need to communicate

\footnotetext{
${ }^{15}$ Fluri (2008); Hunt (2002); Kolhatkar (2010); Charlesworth and Chinkin (2002); Enloe (1990); Enloe (2004).
} 
the aims of the 'War on Terror' to the American public was emphasised and their assistance invoked. ${ }^{16}$ Hollywood and the media rose to this challenge by saturating America in nostalgic stories of good versus evil where the 'allAmerican' hero triumphs over his enemies. ${ }^{17}$ We are told how America reacquainted itself with the heroes of childhood, foreshadowing the celebration of the new hero: ordinary American men who protect the nation; fire-fighters, police officers and construction workers.

As well as being valiant these ordinary Americans were depicted as heroes because of their benevolence and generosity to Afghanistan. President Bush in particular reinforced the image of Americans as generous and compassionate people. He spoke of the American children who were raising money for Afghan orphans and highlighted how the coalition was dropping food parcels alongside its bombs.

At the same time, the oppressed people of Afghanistan will know the generosity of America and our allies. As we strike military targets, we'll also drop food, medicine and supplies to the starving and suffering men, women and children of Afghanistan. ${ }^{18}$

\section{ii. The Hero as 'Masculine'}

It was also argued that the invoking of the heroic narrative in the wake of $9 / 11$ heralded the return of 'traditional masculinity' as a normative hegemonic ideology. ${ }^{19}$ This singular view of masculinity was one which relied on mythological 'male' attributes such as courage, strength, toughness, stoicism and the rejection of the soft and feminine. The evidence for this claim was that, since women's only role in this narrative was as victims, this aided the belief that all women were victims and thereby required strong 'masculine' men to protect them. It is well established that invoking this paradigm creates a justification for increasing militarisation domestically and internationally. ${ }^{20}$

\footnotetext{
16 Alford (2011).

${ }^{17}$ Faludi (2008) p.6.

${ }^{18}$ Bush (7.10.2001).

${ }^{19}$ Brown (2001); Faludi (2008); Noonan (2001); Dowd (2001).

${ }^{20}$ Enloe (2004); Enloe (1990).
} 
As evidence of this return to a strong 'masculine' state, many commentators cited those who argued that in the post 9/11 world traditional gender roles should be embraced as male strength had proved a necessity, ${ }^{21}$ while numerous press reports fixated on the fact that Osama bin Laden had taunted the West for becoming feminised and weak. ${ }^{22}$ It appeared that in letting itself get soft, America had lost the ability to defend itself. This was alluded to by Helene Cixous, who wrote that the destruction of the twin towers was analogous to castration. ${ }^{23}$ Therefore, in order to strike back against the terrorists America needed to reassert its 'masculinity'.

In some ways this machismo obsession was similar to that seen during the Reagan era when, according to Susan Jeffords, 'hard bodies' like Reagan's own came to define politics. ${ }^{24}$ These hard bodies personified strength, aggression and determination and were seen in South America and in the fight against communism. They came to represent the epitome of the nation itself and were in stark contrast to the "weakened... even feminine" years of the previous administration. ${ }^{25}$

\section{iii. The Hero as Uncompromising}

The leader of these 'masculine' men was President Bush himself who was cast in the ultimate western as the righteous sheriff protecting his people from the outlaws. This contemporary re-imagining of the heroic narrative is one that holds appeal for many Americans. Indeed Mead argues that the western is America's founding myth which needs to be continually retold. ${ }^{26}$ While Buchanan and Johnson argue that the narrative of 'frontier justice' is deeply embedded within American Presidential discourse. ${ }^{27}$

As such, Bush was frequently depicted in frontier 'folkisms' calculated to reassure the public and portray him as a capable leader. ${ }^{28}$ He called for Osama bin Laden

\footnotetext{
${ }^{21}$ Goodstein (2001) Noonan (2001).

${ }^{22}$ Burns (2001).

${ }^{23}$ Cixous (2002) p.431.

${ }^{24}$ Jeffords (1994) p. 25.

25 Ibid.

${ }^{26}$ Mead (2010).

${ }^{27}$ Buchan and Johnson (2005) p.141.

${ }^{28}$ Takacs (2010) p. 153.
} 
"Dead or Alive"29 and posited the US as the "reluctant gunslinger forced by circumstances to resort to violence." ${ }^{30}$ Indeed Bush epitomised this characterisation when he challenged the world that if it did not support America then it would be considered to be in league with the terrorists. ${ }^{31}$ Such 'macho' uncompromising language ultimately allowed the Bush Administration to render what was a complicated geo-political crisis into a simplistic Manichean showdown between the 'allies' and the Taliban. Accepting its role as protector and defender, America would have no choice but to reluctantly pursue the 'bad guys'.

\section{Problems with the Hero Construction}

Whilst this characterisation of Bush as the valiant sheriff hunting down outlaws in the name of justice perfectly subscribes to the heroic narrative, many scholars have failed to acknowledge that such characterisation is actually grounded in traditional American political identity. By analysing the particular foreign policy culture and discourse of the US, it can be argued that Bush deliberately crafted a discourse that would resonate strongly with republican voters while also appealing to the mainstream. ${ }^{32}$ Such rhetoric appealed because it positioned the US as tough and un-beholden to other nations while concomitantly creating a climate of fear and paranoia about terrorism and so necessitating military action. Indeed, McLaren notes that the best way of appealing to the American public is for the President to appear "uncompromising... unrestrained, confident, anagogic, and sometimes allegorical." ${ }^{\text {,3 }}$ Therefore it was necessary for Bush to adopt a 'gungho' discourse in order to appear commanding and Presidential even though such discourse lacked detail, sense or considered analysis. ${ }^{34}$

However, while it can certainly be argued that the Western media helped to construct the heroic narrative around OEF by positioning US military masculinity as the saviour of civilisation, merely evidencing this to the re-

\footnotetext{
${ }^{29}$ Bush $\left(17^{\text {th }}\right.$ September 2001). Bush is actually accredited as saying "I want justice, and there's an old poster out West, I recall, that says, 'Wanted: Dead or Alive.'" But this was widely reported in the media as Bush calling for Bin Laden 'Dead or Alive'. See Harnden (2001).

30 Takacs (2010) p.153.

${ }^{31}$ Bush $\left(20^{\text {th }}\right.$ September 2001).

${ }^{32}$ Holland (2013) p. 25.

${ }^{33}$ McLaren (2003) p.327.

${ }^{34}$ Holland (2013).
} 
emergence of 'masculinity' is problematic. The main issue with the hero construct is that this characterisation itself relies on a one-dimensional view of masculinity which is rarely adequately defined. It is also the case that even whilst warning against the stereotypical characterisation of the heroes as masculine, such depiction holds an appeal even to those who critique this narrative. This is alluded to by Tickner who, even while criticising the masculinisation and gendering of $9 / 11$, notes that there is "something reassuring about 'our men' protecting us from 'other men'., 35

Furthermore, such unqualified acceptance of the discourse of one-dimensional masculinity is problematic because it promotes a masculinity enshrined in heteronormativity. Indeed Judith Butler argues that there was a hierarchy of mourning for the victims of the attacks which privileged "those who were married, or on the way to be, heterosexual, happy, monogamous."36 While, several scholars highlight the caricatures of Osama bin Laden being anally penetrated by the Empire State Building; ${ }^{37}$ imagery designed to both taunt and humiliate. ${ }^{38}$ In order for the West to reassert its dominance and 'masculine' superiority the narrative requires that it demonise and dehumanise the third-world 'other' by rendering him feminine and effeminate. While much critical scholarship on the heroic narrative highlights the danger of promoting a dualist view of western masculinity versus eastern femininity, it fails to adequately address the unequal power dynamics which operate to allow the West to hold this view and as such, inadvertently promotes the heteronormative trope which underpins this discourse on 'masculinity'.

\section{Depictions of the 'Other' in the 'War on Terror' Rhetoric}

The heroic narrative literature further tells us that once the US was firmly positioned as the heroic 'masculine' entity willing to fight against evil to protect the innocent; it became necessary to construct both a villain and a victim to complete the narrative because, as Mutua tells us, such characters are

\footnotetext{
35 Tickner (2002) p.339.

${ }^{36}$ Butler (2004) p.32.

${ }^{37}$ Philipose (2008); Puar and Rai (2002).

${ }^{38}$ Philipose (2008).
} 
interdependent. ${ }^{39}$ Indeed both Orford and Mutua note that the heroic narrative is actually an inherent construction of how the west sees itself. Writing on how this narrative operated during the first Gulf War, Heathcote states that "When the West uses force to 'save' another state, it is not the Bedoon or the Kurdish people for whom the narratives are written: the narratives are stories and histories for the West to reflect back its own image." 40 The image in question is of course that the West is heroic and benevolent and by casting ourselves as the hero this position is never questioned.

However, while the casting of the hero proved unproblematic it was somewhat more difficult to cast the villain. In the early days after 9/11 the US Government claimed that Osama bin Laden and the terrorist organisation Al Qaeda were most likely responsible for the attack. However, rather than mount an offensive solely against $\mathrm{Al}$ Qaeda (or pursue them through criminal channels) the US made clear that it would also pursue the Taliban de facto Government of Afghanistan that was reportedly sheltering bin Laden and Al Qaeda terrorists, even though there was little evidence linking the Taliban to $9 / 11 .^{41}$ Clearly the US was aware that an offensive mounted solely against private actors, even if those actors were terrorists, had no basis in international law as self-defence is only appropriate when a state is attacked by another state ${ }^{42}$ or when the actions of private individuals can be attributed to another state. Terrorism has hitherto rarely been regarded as the work of a state because terrorist conduct usually cannot be adequately attributed to a state. ${ }^{43}$ Therefore, the US knew it would be prudent to attribute international responsibility for $9 / 11$ to the Taliban (and therefore the state of Afghanistan) as well as Al Qaeda in order to face less opposition internationally and make UN SC endorsement less controversial. As such, in most mainstream media the Taliban and Al Qaeda came to be seen as one and the same, perhaps because of the US Administration's insistence on vilifying them both.

\footnotetext{
${ }^{39}$ Mutua (2001).

${ }^{40}$ Heathcote (2005) p.149.

${ }^{41}$ The only official account that linked the Taliban to the attacks was a report released by the British Government. UK Government Press Release (2001). However, the 9/11 Commission would later conclude that there was no evidence and that it was highly unlikely that the Taliban had been involved in planning or sanctioning the attacks. The Final Report of the National Commission on Terrorist Attacks Upon the United States (2004).

${ }^{42}$ Legal Consequences of the Construction of a Wall in the Occupied Palestinian Territory, 2004, 43 ILM 1009, 1050 (2004).

${ }^{43}$ GRAY, C. D. 2008. International law and the use of force, Oxford University Press London.p.195-198.
} 


\section{The Villain}

One of the simplest ways to encourage support for war is to demonise one's enemies. Historically this involved merely articulating and exaggerating very real fears that people had about other cultures or civilisations. During WWI the allies demonised the Germans by disseminating stories of their alleged atrocities; stories such as Belgian babies being ripped apart by German soldiers or the German army boiling corpses to render them for fat and oil. ${ }^{44}$ Although these stories were wholly fabricated by the British propaganda machine they were used to great effect by both the US and UK. ${ }^{45}$ However this technique has endured to today and it continues to play on people's fears of the 'other'. Indeed, Harold Lasswell observed how, during World War I, officials decried "the insolence and depravity of the enemy" ${ }^{46}$ and as such he identified a "cult of Satanism" that demonised the enemy so war could be justified. ${ }^{47}$

\section{i. The Villain as Inhuman}

It is interesting that Lasswell used the term Satanism. This suggests it is not enough to portray one's enemy as wicked but as non-human. This construction of the enemy as non-human is done to exploit our perception of others because: "If certain lives are not perceivable as lives, and this includes sentient beings who are not human, then the moral prohibition against violence will only be selectively applied." 48 This way 'civilised' society can be secure of its own identity by juxtaposing it with demons and madmen. As Foucault reminds us "men were men because they were not monsters." ${ }^{49}$

Highlighting this juxtaposition, Johnson and Buchanan demonstrate that in the heroic narrative the villain is identified by endowing him with traits that are binary opposites of those possessed by the hero. ${ }^{50}$ Such depictions provide clear cues to the audience as to whom they should identify with and whom they should vilify.

\footnotetext{
44 Jowett and O'Donnell (2011) p.163.

${ }^{45}$ Ibid.

${ }^{46}$ Lasswell (1971) p.78.

47 Ibid p. 96.

${ }^{48}$ Butler (2009) p51.

${ }^{49}$ Foucault (1965).

${ }^{50}$ Buchanan and Johnson (2005).
} 


\section{ii. Monsters and Demons in the 'War on Terror'}

Consequently, in the 'War on Terror' narrative both the Taliban and Al Qaeda were portrayed as outlaws and as barbarous savages. President Bush initially stated that "barbarians had declared war on America". 51 We were then told how the Taliban were similarly evil and irrational fundamentalists. He was also quick to describe the 'War on Terror' as a war of "good versus evil". 52 Indeed, he frequently referred to the perpetrators as "evil doers" $" 53$ and called them an enemy that "preys on innocent and unsuspecting people." 54 In this way, by constructing his enemies as 'evil' Bush was able to desensitise the public to the destruction of fellow humans. Indeed Anderson tells us that the function of such language is to purposely stifle discussion as to alternative reactions. ${ }^{55}$ It also separates "the evildoer from the ranks of humanity" thereby making it morally acceptable to destroy such people without qualms or legal scrutiny. ${ }^{56}$ Bush continued to use language such as the 'evil doers' to reinforce that morality was on the side of the US while at the same time emphasising that these individuals were without conscience or humanity. Depictions such as this mean that "the terrorist is transformed through the authors' rhetoric from an ordinary deviant into a frightening 'foreign' barbaric beast at the same time that extra-normal means are called for to fight terrorism."57 Such cartography, according to Gregory, was “designed to bring relief to 'us' while bringing 'them' into relief; at once therapeutic and a vengeful gesture, its object was to reveal the face of the other as other." 58

However a more radical interpretation of this demonisation, which the heroic narrative literature fails to address, is that monsters or villains are in fact metaphors for our own demons and reflect our own true self. As such, "Monsters are our Others par excellence. Without them we know not what we are. With them we are not what we know." 59 While much scholarship correctly warns of

\footnotetext{
${ }^{51}$ Bush (15.09.2001)

52 Bush (11.9. 2001).

${ }^{53}$ Bush (19.9.2001).

${ }^{54}$ Bush (11.9.2001).

55 Anderson (2006).

56 Ibid.p.726.

${ }^{57}$ Porras (1994) p.121.

${ }^{58}$ Gregory (2004) p.49.

${ }^{59}$ Kearney (2003) p.28.
} 
the danger of orientalist depictions of monstrous evil Muslim men, it fails to engage with the assertion that such monstrous depictions are our true image. As Devetak warns, "monsters have the unsettling effect of destabilising the very categories and oppositions that Bush and others presuppose."60 Therefore, while much has been written on the heroic narrative's operation in the 'War on Terror' and its need to juxtapose the villain with the hero, there is little analysis or criticism in this literature of the default construction of Al Qaeda or the Taliban as the villain. Instead, most scholarship implicitly affirms the characterisation of both the villain and the hero and instead merely engages in a critique of the depiction of Afghan women as victims. Therefore, it is important to recognise that, despite its apparent attraction there are problems with this default identification. Critical scholarship may baulk at the utilisation of Manichean narratives and one-dimensional characters in the mainstream discourse on the 'War on Terror', however such scholarship itself always approaches the narrative from the perspective that the West is naturally the hero and fails to question or subvert this assumption. Instead the real danger and absurdity of the heroic narrative's subjective reductivism would become apparent if the scholarship demonstrated how bin Laden is equally capable of utilising such a narrative to demonise the West and portray his followers as heroes.

Furthermore, with regard to Al Qaeda, it may be the case that rather than them being intrinsically evil, such abhorrence and vilification reflects discomfort with an essential 'otherness'. The rhizomal nature of Al Qaeda has meant that conventional warfare has been rendered superfluous and ineffective and whilst guerrilla tactics hold a logical appeal to terrorist organisations, Al Qaeda's failure to engage in established warfare or criminality tactics furthers our distrust of them. Indeed it has even been suggested that their 'mystique' is a result of their "apparent panoptic power" 11 in that they were able to see and monitor everyday life and culture in the US, but did not allow the West to see their true selves. Instead they dissolved into shadow and nothingness. Saniotis argues that the West's discomfort stems as much from knowing that the terrorists are outsiders than that they are evil. However there is little willingness to discuss why the categorisation of evil holds such allure, even for those who highlight the existence

\footnotetext{
${ }^{60}$ Devetak (2005) p.642.

${ }^{61}$ Saniotis (2005) p.536.
} 
of the heroic narrative. While the literature is correct to highlight the onedimensional construction of the villain figure it does not go far enough and fails to ask what this depiction says about us. Presumably because, as Kearney reminds us, "The monster remains a personification of our repressed Other. It functions as that negative mirror-image of ourselves." 62

\section{Depicting and Deconstructing the 'Damsel in Distress'}

In the traditional fairy-tale narrative the 'damsel in distress' is a young woman who is viewed as virtuous and chaste. She is epitomised by characters such as Sleeping Beauty, Cinderella or Snow White as she is invariably in danger or difficulty but lacks the agency or capacity to save herself. Instead the reader is invited to sympathise with her plight and then rejoice when she is rescued by the hero. Karen Rowe describes this character as 'impotent' and notes how she is "unable to act independently or self-assertively; she relies on external agents for rescue." ${ }^{63}$ Furthermore, while the damsel's plight may be one of impending mortal peril which evokes sympathy, the nature of the story is not to wholly engage with the causes of this plight but instead for it to serve as a plot device against which the hero can operate. Similarly in the 'War on Terror' narrative the focus on the hero means that the causes of terror are not wholly engaged with. Instead, in this trope the oppressed women of Afghanistan were depicted as the helpless but blank damsels awaiting rescue by the heroic western soldiers.

\section{The Appeal of the Rescue Trope}

Much of the heroic narrative literature notes how this trope was adopted almost immediately after the $9 / 11$ attacks. Indeed on the $17^{\text {th }}$ November 2001 , First Lady Laura Bush delivered the President's address to the nation. She told the American public that women in Afghanistan must not be forgotten and how the "brutal oppression of women was a goal of the terrorists". Similarly, in the UK Cherie Booth (wife of Prime Minister Tony Blair) made a speech highlighting the plight of Afghan women. In the days and weeks that followed, the US Government

\footnotetext{
${ }^{62}$ Kearney (2003) p.29.

${ }^{63}$ Rowe (1979) p.239.
} 
released a document titled 'The Taliban's War Against Women'. ${ }^{64}$ This document emphasised that the 'War on Terror' was also in part, on behalf of women and children.

Reflecting Mutua's observation of the interdependency of the narrative characters, to complement the perfect villain, the perfect victim needed to be sourced. Before 2001 very few people outside of the human rights movement were familiar with the Taliban. In the international arena, the United Nations Security Council passed several resolutions requiring the Taliban to act against terrorism, while the Human Rights Council and its predecessor reported on the Taliban's violation of Human rights throughout the 1990's. The Taliban's treatment of women in Afghanistan was also the subject of a campaign by the Feminist Majority Foundation. However, prior to 9/11 such condemnation had gone virtually unnoticed. Now this fundamentalist organisation that had imposed an orthodox interpretation of sharia law on a poor and war torn country was front-page news. The Taliban were derided as barbarous medieval monsters who hated women almost as much as they hated the West. ${ }^{65}$ Their treatment of Afghan women was soon a prominent discussion in many newspapers and on numerous TV shows. Depictions of Afghan women forced to wear the all-encompassing burqa ran alongside accounts of woman and girls prevented from attending school, accessing healthcare or leaving their homes unaccompanied.

However, the heroic narrative literature correctly asserts that such a focus on the plight of Afghan women was highly sensationalised and reductivist, and in keeping with the fairy-tale depiction, paid little heed to the reality or background of most Afghan women. Instead, Afghan women were offered as victims for the West to save in the 'War on Terror'. Indeed, according to Michaele Ferguson, the highlighting of women's rights was merely another strategy for further emphasising the barbarous and evil nature of the Taliban while emphasising to the public that they were as much the villain as Al Qaeda: "Those who respect their women are civilised, those who do not are barbarians."66 Yet, this equivalence was problematic because legally the Taliban were only guilty of a breach of a due-

\footnotetext{
${ }^{64}$ Bureau of Democracy, Human Rights and Labor, United States of America (2001). 65

${ }^{66}$ Ferguson (2005) p.21.
} 
diligence obligation to hand over bin Laden, rather than as sponsors of terrorist attacks.

Similarly, Sonali Kolhatkar argues that Afghan women were simply utilised as a visual justification for the military action. ${ }^{67}$ She notes how the Taliban's treatment of women was sensationalised and seized on by the western media in order to further amplify the narrative. She describes how Karen Hughes, a counsellor to President Bush, designed a publicity campaign for the White House that widely publicised the suffering of Afghan women. Hughes remarked that she highlighted the women's plight merely to demonstrate the "cruel and evil nature of the people we were up against" rather than as a rallying call to improve the women's lives. ${ }^{68}$

Indeed, much of the literature focusses on the hypocrisy of Western leaders and the media in depicting Afghan women as the oppressed subjects for whose benefit the 'War on Terror' would be fought. ${ }^{69}$ Such scholarship is correct to assert how the depiction of Afghan women as victims ultimately rendered them silent however it does not go far enough because that scholarship itself only sees them as one-dimensional and tellingly does not engage with the women themselves.

\section{The Effect of the Rescue Trope: Silencing Afghan Women}

Afghan women's groups were demonstrably vocal immediately before and after the start of Operation Enduring Freedom, however they were often ignored. ${ }^{70}$ This would become a recurring theme throughout discourses about Afghan women: the lack of agency given to Afghans and their opinion on the US intervention. Brittain notes the criticism of the Feminist Majority Foundation (FMF) "for claiming a foremost role in 'freeing' Afghan women and failing to give 'any credit to the independent Afghan women who stayed in Afghanistan' and worked against the Taliban."71 Meanwhile the Afghan Women Network, a group whose members were professional Afghan refugee women in Pakistan, reported that they were left

\footnotetext{
${ }^{67}$ Kolhatkar and Ingalls (2010).

${ }^{68}$ Ibid.p.173.

${ }^{69}$ Kolhatkar and Ingalls (2010); Fergusson (2005); Hawthorne (2002); Hunt (2002); Hunt and

Rygiel (2006); Fluri (2008); Ayotte and Husain (2005); Shepherd (2006).

${ }^{70}$ Khattak (2002).

${ }^{71}$ Brittain (2006) p.61.
} 
"confused, insulted, hurt, angry and substantially ignored"72 by the UN Gender Mission on its visit to Pakistan. The group criticised the Mission's Head Angela King for failing to spend any time with "actual Afghan women" yet purporting to speak on their behalf at the UN. ${ }^{73}$ As such, Fluri notes how, while they were highlighting women's rights in Afghanistan and drawing attention to Taliban atrocities such as stoning, the FMF failed to credit the Revolutionary Association of the Women of Afghanistan (RAWA), a prominent and active Afghan women's organisation, for filming the atrocities and in doing so alerting the wider world to the situation. ${ }^{74}$ Indeed, although RAWA is a strong grass roots organisation with valuable expertise in providing social programs to women, it has been marginalised by the west (perhaps because of its revolutionary mandate and Marxist leanings) and so gives further credence to the accusation that women as victims merely provide a potent symbol around which to marshal support for the 'War on Terror'.

In view of this, such scholarship is correct to highlight how the one-dimensional characterisation of the damsel in distress can and did result in the silencing of Afghan women. However, whilst the scholarship is correct to highlight the effect of this characterisation- it fails to focus that same critique on the West's characterisation of itself in the narrative. Post-colonial scholarship tells us that the depiction of Afghan women solely as victims suggests that that the West feels more comfortable viewing them as passive objects that cannot speak for themselves, however as Spivak warns, there are insurmountable problems when Western feminists try to speak for third world women. ${ }^{75}$ Yet the scholars who critique the heroic narrative often fall foul of this warning and fail to convince why they are immune from such imperialist construction.

Instead much of the heroic narrative critique highlights how the media's co-option of Afghan women's oppression is dangerous to feminism. We are told that in addition to the heroic narrative simplifying the climate of intervention it also raises false expectations of the outcome of that intervention. In subscribing to this

\footnotetext{
${ }^{72}$ Khattak (2002) p.21.

${ }^{73}$ Ibid.

${ }^{74}$ Fluri (2008).

${ }^{75}$ Spivak (2008).
} 
narrative in order to feel safe and protected, Americans told themselves that their military would help improve the lives of Afghan women even when there is little evidence to suggest that this would be the likely outcome. Indeed many scholars have analysed the rhetoric that championed Afghan women's rights and they demonstrate that even in the early days of 2001, the Bush Administration was never sincere in its desire to promote women's rights. ${ }^{76}$ Indeed, while it utilised the language of feminism to sell the 'War on Terror', the preoccupation with Afghan women's rights allowed it to encroach on women's rights in domestic politics causing American women to experience severe cutbacks in unemployment compensation, disability insurance, health benefits, and access to reproductive choice. 77 Furthermore, the US is also one of only a handful of states that are not party to the CEDAW.

However in its attempt to highlight this pertinent point, such scholarship often ignores the diverse range of women, or give credit to Afghan women with opposing views and therefore may inadvertently marginalise or negate the experience of those women who suffered very real harm or oppression and who may be correct to look to outside militaries or regimes for assistance. By overly focussing on the depiction of women as victims and how this silences women, the heroic narrative literature fails to address the fact that actual women may benefit from military action.

\section{The Limitations of the Heroic Narrative Critique}

The heroic narrative literature cautions those feminist activists and scholars who were willing to endorse the promulgation of the heroic narrative because they were aware of the heightened exposure it could bring. Because of such complicity, there was little discussion in the media of the complicated geo-politics that affected Afghanistan or of the rich and diverse cultures adopted by its people. Instead, Kolhatkar writes that the over-simplified narrative sensationalised the Taliban abuse by implying that Afghan women's oppression was limited to the burqa and that burqa-clad women needed saving from the Taliban by the West. ${ }^{78}$

\footnotetext{
76 Charlesworth and Chinkin (2002); Kolhatkar and Ingalls (2010); Ferguson (2005); Faludi (2008);Hunt (2006); Hunt (2002); Fluri (2008); Shepherd (2006).

${ }^{77}$ N. Gallagher, 'Liberating Afghan Women' 21 American Journal of Islamic Social Sciences 70.

${ }^{78}$ Kolhatkar and Ingalls (2010).
} 
She also notes how little attempt was made to understand the nature and history of the burqa or its origins. Instead the media mainly implied that before the 'barbarous' Taliban, Afghan women had been free and lived parallel lives to western women. Freeing them from their burqas, or unveiling them, was the key to liberating women to lead western style lives. Such homogenised accounts of Afghan women and their lives make over-generalized claims about women and subscribe to gender and culture essentialism. ${ }^{79}$

However, like those they critique, the scholars who highlight the operation and dangers of the heroic narrative are similarly only able to view the women of Afghanistan as passive, silent and oppressed. Even by critiquing the role of the 'damsel in distress' the scholarly critique continues to homogenise and standardise the accounts of Afghan women in order to present a neat and logical rebuttal of this victim status. While such literature is correct in many of the criticisms it raises, the reality is that Afghan women as a collective can be neither completely passive nor fully autonomous agents and yet the many conflicting voices of the women themselves are very rarely engaged with, far less critiqued. Instead it is those who eschew behaviour that rejects their status as victims who are celebrated by the authors and those whose suffering made the western news that are inadvertently juxtaposed by such scholarship. In attempting to demonstrate how the heroic narrative renders all Afghan women victims and how this is problematic, the critique itself falls victim to a similar failure. In focussing solely on women's victimisation and silence, this critique ignores the flaws in its own argument. It does not adequately address the issue of those women who chose to assert their own voice but in doing so affirm the dominant understanding that many Afghan women are victims of oppression, and due to the patriarchal norms and practices of their society, face insurmountable difficulties in changing this reality and so may actually benefit from outside assistance.

\section{The Failure to Engage with Less Palatable Narratives}

\section{i. The US as the Victim and the Need for Retribution}

In the immediate aftermath of the terrorist attacks there was an understandable raw outpouring of emotion from both public and authority figures. However,

${ }^{79}$ See Kapur (2002); Mohanty (2002). 
according to Jackson this was evolved into a "myth of exceptional grievance," 80 the main purpose and consequence of which was to establish and solidify America's status as the victim. However, a consequence of this grievance myth is that it removes moral responsibility and accountability for counter-violence. Indeed Jackson argues that one of the most horrific consequences of perpetuating the trope of victimhood-through both the language and practices of officials, such as showing army recruits footage of 9/11- was the gross human rights violations at Abu Ghraib prison. By reinforcing the belief that the USA was the victim and not the aggressor, the "discursive construction of exceptional suffering made the daily humiliations handed out to prisoners in Abu Ghraib prison seem inconsequential compared with the atrocity of 9-11." ${ }^{.1}$

Despite this, the trope of American victimisation, with its appalling effects, was rarely commented upon, particularly by those feminist authors who sought to establish how the US was conforming to the heroic narrative by focussing on tropes of 'masculinity'. Again this suggests that the heroic narrative critique proves an attractive frame through which to situate the 'War on Terror' rhetoric. So attractive that it allows scholars to ignore the darker and more fragmented gothic narratives that also abound. The lone exception to this silence was Judith Butler who advocated harnessing this sense of vulnerability and loss to create a positive feminist response to 9/11 rather than one based on "violent acts of sovereignty" 82 She asks why experiences of fear and grief must automatically lead to military violence and retribution and suggests an alternative approach: a globalised humanity through which to frame the $9 / 11$ attacks. ${ }^{83}$

The dislocation from first world privilege, however temporary, offers a chance to start to imagine a world in which that violence might be minimised, in which an inevitable interdependency becomes acknowledged as the basis for global political community. ${ }^{84}$

\footnotetext{
${ }^{80}$ Jackson (2005).

${ }^{81}$ Jackson (2005) p.37.

${ }^{82}$ Butler (2004).

${ }^{83}$ Butler (2004).

${ }^{84}$ Butler (2004). Preface xii.
} 


\section{Ignoring Alternative Discourse}

One example of a less simplistic narrative was Tony Blair's conceptualisation of the 'War on Terror' as a kindness to the world community and also to the people of Afghanistan. The effect of his imagery was admittedly the same; the British public conceptualised the invasion of Afghanistan and the wider 'War on Terror' as an act of benevolence and liberation towards the people of Afghanistan. However, although this was grounded in tropes borrowed from heroic and colonial narratives of saving people, it relied on a more nuanced approach to international relations and the theme of saving Afghan women did not feature prominently in the discourse. Notions of saving women were incorporated into wider British tropes about spreading human rights and creating a fairer world. There was much talk of the intervention in Afghanistan being difficult but necessary: the right thing to do. ${ }^{85}$ Indeed Blair strongly focused on promoting global human rights and equality as a means of tackling the increasing terrorist threat. ${ }^{86}$ Even the Iraq War would later be justified by "humanitarianism as well as determinism". ${ }^{87}$ Furthermore, Blair also saw the Arab/Israeli conflict as being intrinsically linked to the success of the 'War on Terror' and advised the US to restart the peace process. ${ }^{88}$

In view of this, it is argued that while the heroic narrative of saving women is an appealing and enduring one, it was not the only narrative underpinning OEF. Particularly as regards the US rhetoric, the initial narratives centred on retaliation, retribution and portraying a stronger America. It was only after the military operation commenced that the US elevated the humanitarian heroic narrative to the forefront. This is confirmed by Wolfe, who argues that OEF as a humanitarian mission emerged as an idealist thematic frame which peaked after the military operation was sanctioned. ${ }^{89}$ He notes that this fits the familiar pattern whereby after the initial show of strength and prowess there is often a need for an emotional, as well as a rational appeal to go to war. Humanitarianism helps actors

\footnotetext{
${ }^{85}$ Holland, 'Blair's War on Terror: Selling Intervention to Middle England'.

${ }^{86}$ N.L. Fairclough, 'Blairs contribution to elaborating a new doctrine of international community' 4 Journal of Language and Politics 41.

${ }^{87}$ P. Hoggett, 'Iraq: Blair's mission impossible' 7 The British Journal of Politics \& International Relations 418, p.422.

${ }^{88}$ Coughlin, American ally: Tony Blair and the war on terror, p.164.

${ }^{89}$ Wolfe (2008).
} 
to believe they are doing a good deed even when they are waging war. Therefore once the coalition military might was turned on the people of Afghanistan there was a need to reposition OEF within this alternative narrative. However it is interesting that feminist scholars were so keen to focus their critique on this particular narrative at the expense of others.

\section{Conclusion}

This paper sought to explore how the familiar heroic narrative operated post $9 / 11$ and draw attention to the failures of the critique of this narrative in contemporary scholarship.

It has argued that the major failing with most scholarly attributions of the heroic narrative is the failure to recognise that the narrative can just as easily be appropriated by the 'other' and reversed to cast him as the hero and the US as the villain. Despite the unassailable logic of this, there is reluctance on the part of Western scholars to acknowledge that the male characters in the narrative are entirely interchangeable and therefore we can gain little insight from them. Therefore it is necessary to be wary and mindful of this when attributing narratives to international events. Such readiness to affirm the heroic narrative and the West's position as the hero ought to be questioned because we can learn little from such depictions if we do not admit that such a tendency exists.

A re-reading of this narrative highlights how the heroic narrative itself projects a dangerous Western image on all the characters and equally posits their salvation (both the victim and villain's) through becoming less 'other' and more like us. Such a critique might invoke Devotaks's postmodern gothic narratives as an alternative reading of the 'War on Terror' to allow weakness, fear, desolation and mistrust to feature and therefore reflect our very real anxieties.

Furthermore, in the heroic narrative which positions the 'civilised against the barbarians', the 'innocent against the damned' and the 'courageous against the cowards', the self and the 'other' have already been cast. As such, this narrative calls for the rescue of the feminine victim by making her into the image of 
ourselves but fails to bestow her with any personality or autonomy. Therefore, the heroic narrative holds an enduring appeal as the dominant and encompassing narrative, not only to mainstream audiences but to critical scholars, because not only do we identify with (and as) the hero- and rescue the victim- we make her like us and through this transformation the villain is vanquished and our heroics confirmed. The attraction of the heroic trope is as enduring to feminist scholars, who inadvertently cast themselves as heroes through their ability to speak for Afghan women, as it is for the mainstream Western media.

However, while much of the scholarship that draws parallels between Afghan women and damsels in need of rescue is problematic due to its refusal to engage with the concomitant narratives, such scholarship does highlight a pertinent point; that when politicians claim to be acting in the name of women's rights, such campaigns run the risk of being misappropriated and reduced to mere rhetoric. Indeed Hunt and Rygiel are correct to state that, far from being a war for women's rights, the 'War on Terror' is, "in fact a war on women's rights." 90

\section{References}

Abu-Lughod, L. (2002). 'Do Muslim women really need saving? Anthropological reflections on cultural relativism and its others.' 104 American anthropologist 783.

Anderson JF, (2006) 'The rhetorical impact of evil on public policy' 37 Administration \& Society 719.

Anghie A and Chimni BS, (2003) 'Third World Approaches to International Law and Individual Repsonsibility in Internal Conflicts’ 2 Chinese Journal of International Law 77.

Ayotte and Husain, (2005) 'Securing Afghan Women: Neocolonialism, Epistemic Violence, and the Rhetoric of the Veil' 17 NWSA Journal 112.

Charlesworth H and Chinkin C, (2002)'Sex, gender, and September 11' 96 The American Journal of International Law 600.

Cixous H, (2002)'The towers: Les tours' 28 Signs 431.

Cloud DL, (2004) "“To veil the threat of terror": Afghan women and the〈 clash of civilizations $\rangle$ in the imagery of the US war on terrorism' 90 Quarterly Journal of Speech 285.

Cooke M, (2002) ‘Gender and September 11: A Roundtable: Saving Brown Women’ 28 Signs 468 .

Cover RM, (1983) 'Foreword: Nomos and narrative' 97 Harvard Law Review 4.

Devetak R, ( 2005) 'The Gothic scene of international relations: ghosts, monsters, terror and the sublime after September 11'31 Review of International Studies 621.

${ }^{90}$ K. Hunt and K. Rygiel (2006), p.11. 
Elliot KC, (2004) 'Subverting the Rhetorical Construction of Enemies Through Worldwide Enfoldment' 27 Women and Language 9.

Ferguson ML, (2005)“"W” Stands for Women: Feminism and Security Rhetoric in the Post-9/11 Bush Administration' 1 Politics \& Gender 9.

Heathcote G, (2005)`Article 51 Self-Defense as a Narrative: Spectators and Heroes in International Law' 12 Texas Wesleyan Law Review 131.

Hunt, K. (2002). 'The strategic co-optation of women's rights.' 4 International Feminist Journal of Politics 116.

Jabbra, N. W. (2006). 'Women, words and war: explaining 9/11 and justifying US military action in Afghanistan and Iraq.' 8 Journal of International Women's Studies 236.

Jiwani, Y. 'Helpless Maidens and Chivalrous Knights: Afghan Women in the Canadian Press.' university of toronto quarterly 78, no. 2 (2009): 728-44.

Johnson R, (2002) 'Defending Ways of Life The (Anti-) Terrorist Rhetorics of Bush and Blair' 19 Theory, Culture \& Society 211.

Khalid, M. (2011). 'Gender, orientalism and representations of the 'Other' in the War on Terror.' 23 Global Change, Peace \& Security 15.

Kapur R, (2002) 'Tragedy of Victimization Rhetoric: Ressurecting the" Native" Subject in International/Post-Colonial Feminist Legal Politics, The' 15 Harvard Human Rights Journal 1.

Kearney R, (2003) 'Terror, philosophy and the sublime Some philosophical reflections on 11 September' 29 Philosophy \& social criticism 23.

Khattak SG (2002) 'Afghan Women’ 222 Middle East Report 18.

Lorber J, (2002)'Presidential Address: Heroes, Warriors, and Burqas: A Feminist Sociologist's Reflections on September 11' 17 Sociological Forum 377.

McLaren P, (2003) 'George Bush, apocalypse sometime soon, and the American imperium' 2 9-11 in American Culture 147.

Mohanty CT, (2002) 'Under Western eyes: Feminist scholarship and colonial discourses' Feminist review 61.

Mutua M, (2001) 'Savages, victims, and saviors: the metaphor of human rights' 42 Harvard International Law Journal 201.

Murphy, Therese, and Noel Whitty. (2006) 'The Question of Evil and Feminist Legal Scholarship.' 14 Feminist Legal Studies 1.

Orford A, (1999)'Muscular humanitarianism: reading the narratives of the new interventionism' 10 European Journal of International Law 679.

Porras IM, (1994)‘On Terrorism: Reflections on Violence and the Outlaw’ Utah Law Review 119.

Rowe KE, (1979) 'Feminism and fairy tales' 6 Women's Studies: An Interdisciplinary Journal 237. Puar, J. K, and Rai, A. (2002) 'Monster, Terrorist, Fag: The War on Terrorism and the Production of Docile Patriots.’ 20 Social Text 117.

Saniotis A, (2005) 'Re-Enchanting Terrorism: Jihadists as "Liminal Beings", 28 Studies in Conflict \& Terrorism 533.

Stabile CA and Kumar D, (2005)'Unveiling imperialism: media, gender and the war on Afghanistan' 27 Media, Culture \& Society 765. 
Schueller, M. J. (2011). 'Cross-Cultural Identification, Neoliberal Feminism, and Afghan Women.' 53 Genders 3.

Shepherd, L. J. (2006). 'Veiled references: Constructions of gender in the Bush administration discourse on the attacks on Afghanistan post-9/11.' 8 International Feminist Journal of Politics 19.

Tickner J, (2002)'Feminist perspectives on 9/11'3 International Studies Perspectives 333.

Wright S, (2002)'The Horizon of Becoming: Culture, Gender and History after September 11 '(2002)' 71 Nordic Journal of International Law 215.

Judith Butler (2004) Precarious Life: The Powers of Mourning and Violence, Verso: London \& New York.

Judith, Butler. (2009) Frames of War: When Is Life Grievable, Verso: London \& New York. Chandler D, (2006) From Kosovo to Kabul and beyond: Human rights and international intervention, Pluto, Ann Arbor .

Eisenstein, Z. R. (2004). Against empire: Feminisms, racism, and the West, Zed Books.

Enloe, C. (1990) Bananas, Beaches \& Bases: Making Feminist Sense of International Politics, University of California Press, Berkeley.

Enloe CH, (2004) The curious feminist: Searching for women in a new age of empire, University of California Press.

Faludi S, (2008) The terror dream: What 9/11 revealed about America, Atlantic Books.

Foucault M (1965) Madness and Civilization: A History of Insanity in the Age of Reason, Random House Publishing.

Gregory D, (2004) The Colonial Present: Afghanistan, Palestine, Iraq, Wiley-Blackwell.

Hawthorne, S. and B. Winter (2002). September 11, 2001: feminist perspectives, Spinifex Press. Holland J, (2013) Selling the War on Terror: foreign policy discourses after 9/11, Routledge. Hunt K and Rygiel K, (2006) (En) gendering the war on terror: war stories and camouflaged politics, Ashgate Pub Co.

Jackson R, (2005) Writing the war on terrorism: language, politics and counter-terrorism, Manchester University Press.

Jeffords S, (1994) Hard bodies: Hollywood masculinity in the Reagan era, Rutgers University Press.

Jowett GS and O'Donnell V, (2011) Propaganda \& persuasion, Sage Publications.

Kolhatkar S and Ingalls J, (2010) Bleeding Afghanistan: Washington, warlords, and the propaganda of silence,Seven Stories Press.

Lasswell HD, (1971) Propaganda technique in World War I, MIT Press.

McLintock, A. (1995). Imperial Leather: Race, gender and sexuality in the colonial context, New York: Routledge.

Meier H, (1998) The lesson of Carl Schmitt: four chapters on the distinction between political theology and political philosophy, University of Chicago Press.

Orford A, (2003) Reading humanitarian intervention: human rights and the use of force in international law, Cambridge University Press. 
Taylor PM, (2003) Munitions of the Mind: A History of Propaganda, Manchester University Press.

Wolfe WM, (2008) Winning the war of words: selling the war on terror from Afghanistan to Iraq, Praeger Publishers.

Alford M, (2011) 'Why Not a Propaganda Model for Hollywood?' in Hammond P (ed), Screens of Terror: representations of war and terrorism in film and television since 9/11, Arima Publishing. Brittain, M. (2006) 'Benevolent Invaders, Heroic Victims and Depraved Villains: White Femininity in Media Coverage of the Invasion of Iraq.' In (En) Gendering the War on Terror: War Stories and Camouflaged Politics, edited by K. Hunt and K. Rygiel, Ashgate Publishing Co. Buchanan R and Johnson R, (2005) 'The Unforgiven sources of international law: Nationbuilding, violence, and gender in the West (ern)' in Buss D and Manji A (eds), International Law: Modern Feminist Approaches, Oxford: Hart Publishing.

Fluri JL, (2008) 'Rallying public opinion and other misuses of feminism' in Feminism and war: Confronting US imperialism, edited by RL Riley, CT Mohanty and MB Pratt, Zed.

Mead, '9/11, (2010) Manhood, Mourning and the American Romance' in Birkenstein J, Froula A and Randell K, Reframing 9/11: film, popular culture and the" war on terror", Continuum International Publishing Group.

Philipose, E. (2008) "Decolonizing the Racial Grammar of International Law in Feminism and war: Confronting US imperialism, edited by RL Riley, CT Mohanty and MB Pratt, Zed.

Spivak GC, (1988) 'Can the subaltern speak?' in Nelson C and Grossberg L (eds), Marxism and the Interpretation of Culture, University of Illinois Press.

Takacs, Stacy. (2010) 'The Contemporary Politics of the Western Form: Bush, Saving Jessica Lynch and Deadwood.' in Birkenstein J, Froula A and Randell K, Reframing 9/11: film, popular culture and the" war on terror", Continuum International Publishing Group.

Zine, J. (2006). Between Orientalism and fundamentalism: Muslim women and feminist engagement. In (En) Gendering the War on Terror: War Stories and Camouflaged Politics. K. Hunt and K. Rygiel, Ashgate Publishing Co.

Bureau of Democracy, Human Rights and Labor, United States of America (2001) Report on the Taliban's War Against Women, (Nov. 17, 2001), available at http://www.state.gov/j/drl/rls/c4804.htm.

The Final Report of the National Commission on Terrorist Attacks Upon the United States (2004) available at http://govinfo.library.unt.edu/911/report/index.htm.

UK Government Press Release, (2001) 10 Downing Street Newsroom, Responsibility for the Terrorist Atrocities in the United States, 11 September 2001 (Oct. 4, 2001) available at http://www.number-10.gov.uk/newsId=2686>. This document was subsequently updated on November 14, 2001. Also available at http://newsrss.bbc.co.uk/1/hi/uk_politics/1579043.stm. Brown PL (2001) 'Ideas \& Trends; Heavy Lifting Required; the Return of the Manly Men' New York Times (New York, 26 October 2001).

Burns J, (2001) 'A NATION CHALLENGED: THE WANTED MAN' New York Times (New York, 8 October, 2001)

Dowd M,( 2001) 'Liberties; Hunks and Brutes’ New York Times (New York, 28 November 2001). 
Goodstein L, (2001) 'Fallwell: Blame abortionists, feminists and gays', The Guardian (London, 19 September 2001).

Harnden T (2001) 'Bin Laden is wanted dead or alive says Bush', The Telegraph (London 18 September 2001).

Noonan P, (2001) 'Welcome Back, Duke: From the ashes of Sept. 11 arise the manly virtues.' The Wall Street Journal (New York, 12 October 2001).

Bush (11.9. 2001) Remarks at Photo opportunity.

Bush (15.09.20001) Remarks by the President, Secretary of State Colin Powell and Attorney

General John Ashcroft available at http://avalon.law.yale.edu/sept11/president_013.asp.

Bush (20.11.2001) available at

http://georgewbush-whitehouse.archives.gov/news/releases/2001/09/20010920-8.html.

Bush (7.10.2001). 